\title{
Rodent Abundance and Hantavirus Infection in Protected Area, East-Central Argentina
}

\section{Malena Maroli, ${ }^{1}$ María Victoria Vadell, ${ }^{1}$ Paula Padula, Isabel E. Gómez Villafañe}

We captured 3 hantavirus rodent hosts in Otamendi Natural Reserve, Argentina, during 2007-2012. Hantavirus antibodies were found only in Akodon azarae grass mice, mainly in males and old animals. Higher abundance of this species was associated with warm and rainy weather and high water levels, which peaked after a strong El Niño event.

$\mathrm{H}$ antavirus pulmonary syndrome is an emerging infectious disease caused by New World hantaviruses (family Hantaviridae) and transmitted by rodents of the family Cricetidae (1). In Argentina, 7 native rodent species have been identified as hantavirus reservoirs (2). Three of these species (Oligoryzomys flavescens [yellow pigmy rice rat], host of Lechiguanas virus; O. nigripes [black-footed pigmy rice rat], host of Juquitiba virus; and Akodon azarae [grass mouse], host of Pergamino virus) are present in east-central Argentina. A. azarae mice have not been associated with cases of hantavirus pulmonary syndrome (2). The purpose of this long-term study was to identify factors affecting hantavirus infection and reservoir abundance.

\section{The Study}

We conducted a study in 6 habitats in the Otamendi Natural Reserve $\left(34^{\circ} 10^{\prime} \mathrm{S}, 58^{\circ} 48^{\prime} \mathrm{W}\right)$ (online Technical Appendix, https:/wwwnc.cdc.gov/EID/article/24/1/17-1372Techapp1.pdf) in Buenos Aires, Argentina, an area with low anthropogenic and no rodenticide pressures. Rodents were live-trapped during September 2007-December 2012. During December 2011-December 2012, for logistic and security reasons, trapping was concentrated in lowlands, salty grasslands, and highlands containing Ligustrum spp. Traps were baited with a mixture of peanut butter, fat, and rolled oats, placed every $10 \mathrm{~m}$ on permanent grids or

Author affiliations: Centro de Investigaciones Científicas y Transferencia de Tecnología a Producción, Diamante, Argentina (M. Maroli); Universidad de San Martín, San Martin, Argentina (M.V. Vadell); Instituto Nacional de Enfermedades Infecciosas Administración Nacional de Laboratorios e Institutos de Salud Dr. Carlos G. Malbrán, Buenos Aires, Argentina (P. Padula); Consejo Nacional de Investigaciones Científicas y Técnicas, Buenos Aires (I.E. Gómez Villafañe); Universidad de Buenos Aires, Buenos Aires (I.E. Gómez Villafañe)

DOI: https://doi.org/10.3201/eid2401.171372 transects, depending on the shape of each habitat, and set for 3 consecutive nights.

We ear-tagged each captured rodent; identified its species, breeding status, body length (an indicator of age) and body mass; and obtained a blood sample from a cut on the tip of the tail to test for hantavirus antibody (3). Rodents were released at point of capture. We calculated trap success (number of captured rodents/number of trapnights), species richness, abundance ratio $\left(\mathrm{TS}_{\mathrm{i}} / \mathrm{TS}_{\text {total }}\right)$, the Shannon-Weaver Diversity Index, and hantavirus antibody prevalence by species, habitat, and trap session. We calculated body condition as weight divided by the cube of body length.

We recorded percentages of green/dry grass and broadleaf cover $1 \mathrm{~m}$ in height, bare ground, and maximum vegetation height during April 2009-December 2012 by using a $1-\mathrm{m}^{2}$ quadrant placed around each trap station (4). We calculated maximum and minimum temperatures, monthly rainfall, and number of days with temperatures $<0^{\circ} \mathrm{C}$ during the month before each trapping session. These variables were also used with time lags of 1 and 2 months. We determined anomalies in temperature by using the Oceanic Niño Index (5). We recorded mean, maximum, and minimum water levels in the Paraná River during the month before each trapping session and the number of months since the last flooding event for each trapping session.

We assessed associations between hantavirus infection (estimated as antibody prevalence) and vegetation, hydrologic, meteorologic, and rodent population characteristics; presence of hantavirus antibody and individual characteristics; and known hantavirus host abundance and vegetation, hydrologic, and meteorologic characteristics. Analyses were conducted by using logistic regressions with forwardstepping selection and binomial family distributions of errors and logit link or clog-log functions (6) in R software (multcomp and car packages) (7).

During the study period, we captured 650 animals 752 times during 15,833 trap-nights. We captured 3 known hantavirus rodent host species: A. azarae grass mice $(\mathrm{n}=204), O$. flavescens yellow pigmy rice rats $(\mathrm{n}=36)$ and $O$. nigripes black-footed pigmy rice rats $(\mathrm{n}=20)$. We also captured 6 other species: Oxymycterus rufus red hocicudos $(\mathrm{n}=223)$, Scapteromys aquaticus swamp rats $(\mathrm{n}=129)$, Deltamys kempi Kemp grass mice $(\mathrm{n}=27)$, Calomys laucha

${ }^{1}$ These authors contributed equally to this article. 


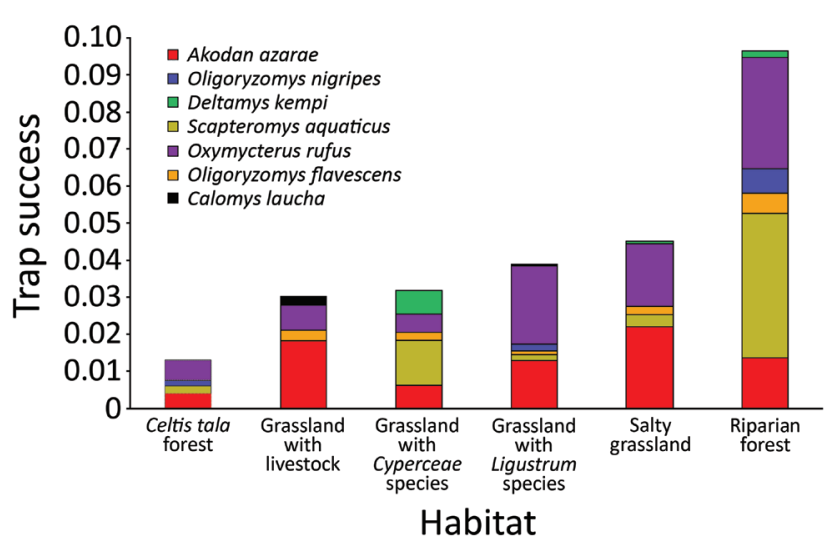

Figure 1. Trap success (no. animal captures/trap-night) by rodent species in each habitat of Otamendi Natural Reserve, Argentina, 2007-2012. Cavia aperea Brazilian guinea pigs and Holochilus sp. marsh rats were not included because too few animals were captured.

small vesper mice $(\mathrm{n}=7)$, Cavia aperea Brazilian guinea pigs $(\mathrm{n}=3)$, and Holochilus sp. marsh rats $(\mathrm{n}=1)$ (Figure 1).

We detected hantavirus antibodies in $A$. azarae grass mice (Table 1) and in 1 D. kempi Kemp grass mouse. In the study area, $A$. azarae grass mice are the known reservoirs of Pergamino virus, a hantavirus variant that has not been associated with human disease $(2,8)$. However, because virus mutations can result in infection of other hosts, constant monitoring is needed. Antibodies in the D. kempi Kemp grass mouse were probably caused by a spillover event (2). Maroli et al. (9) demonstrated that $A$. azarae grass mice share regions with other rodents, suggesting that these mice could promote spillover infections. Antibody prevalence in A. azarae grass mice was $23.9 \%$, which exceeded prevalences reported in other areas of the Argentinean pampas (10).

We captured antibody-positive rodents at every site (Table 1; online Technical Appendix Figure 2) but results showed no evidence of spatial focality, in contrast to what has been reported for other hantavirus-rodent systems $(11,12)$. Significantly greater prevalence was associated with low green grass cover (estimate $-0.03721, \mathrm{p}=$ 0.050 ). Although variation in antibody prevalence among seasons was not significant, absence of continuous trapping of antibody-positive rodents throughout the study (online Technical Appendix Figure 2) suggests that temporary local virus extinctions might be a factor in some local populations, which would later have virus reintroduced from nearby source populations (12). However, these results should be interpreted cautiously because they might be caused by a failure to detect low levels of antibody in these populations.

The effect of community characteristics on disease risk is a topic of current debate (13). Hantavirus antibody prevalence was not associated with any of the community variables analyzed. However, this lack of association with environmental variables cannot be considered conclusive because of difficulties in assessing the role of environmental factors in such a complex system.

Antibody-positive $A$. azarae grass mice were more likely to have a longer body length (mean $106 \mathrm{~mm}$, estimate $0.0929 ; \mathrm{p}<0.001$ ) (Table 1 ) than antibody-negative mice (mean length $98 \mathrm{~mm}$ ), suggesting that hantavirus transmission among rodents is primarily horizontal, as reported for many hantavirus-reservoir systems (1). In addition, male $A$. azarae grass mice (estimate 1.4440; $\mathrm{p}=$ 0.0027 ) (Table 1) were more frequently infected than female mice, probably because of aggressive encounters with other rodents (1). Maroli et al. (9) reported that longer $A$. azarae grass mice travel greater distances, increasing the probability of intraspecific encounters and potential hantavirus transmission.

Abundance of hantavirus host species in the Otamendi Natural Reserve was generally associated with warm and rainy weather and high water levels; abundance was highest after a strong El Niño event and lowest after a strong La Niña event (Figure 2; Table 2). These variables might indirectly affect rodent population abundance as proposed in the trophic cascade hypothesis (14).

We captured A. azarae grass mice in all habitats (Figure 2), showing that this species can occupy many areas and sites with low vegetation heights (Table 2). We also trapped $O$. flavescens yellow pigmy rice rats in 5 of 6 habitats but at lower rates (Figure 1; Table 2), consistent with other studies showing that this species is not dominant in the rodent community (15). Low abundance and short-distance movements (9) might restrict virus dispersal among habitats and could be the reason for the lack of detection of virus antibody. O. nigripes black-footed

\begin{tabular}{|c|c|c|c|c|}
\hline Habitat & $\begin{array}{l}\text { A. azarae trap success rate } \\
(\text { no. })^{*}\end{array}$ & Males, $\%$ & Body length, $\mathrm{mm}$ & $\begin{array}{c}\text { Hanatavirus antibody } \\
\text { prevalence, } \%\end{array}$ \\
\hline Riparian forest & $0.014(23)$ & 70 & 102 & 35 \\
\hline Celtis tala forest & $0.004(8)$ & 63 & 99 & 25 \\
\hline Lowland grassland with Cyperaceae & $0.006(22)$ & 59 & 103 & 35 \\
\hline Highland grassland with Ligustrum spp. & $0.013(44)$ & 61 & 93 & 2 \\
\hline Highland grassland with livestock & $0.018(32)$ & 54 & 99 & 28 \\
\hline Salty grassland & $0.022(75)$ & 61 & 99 & 29 \\
\hline
\end{tabular}




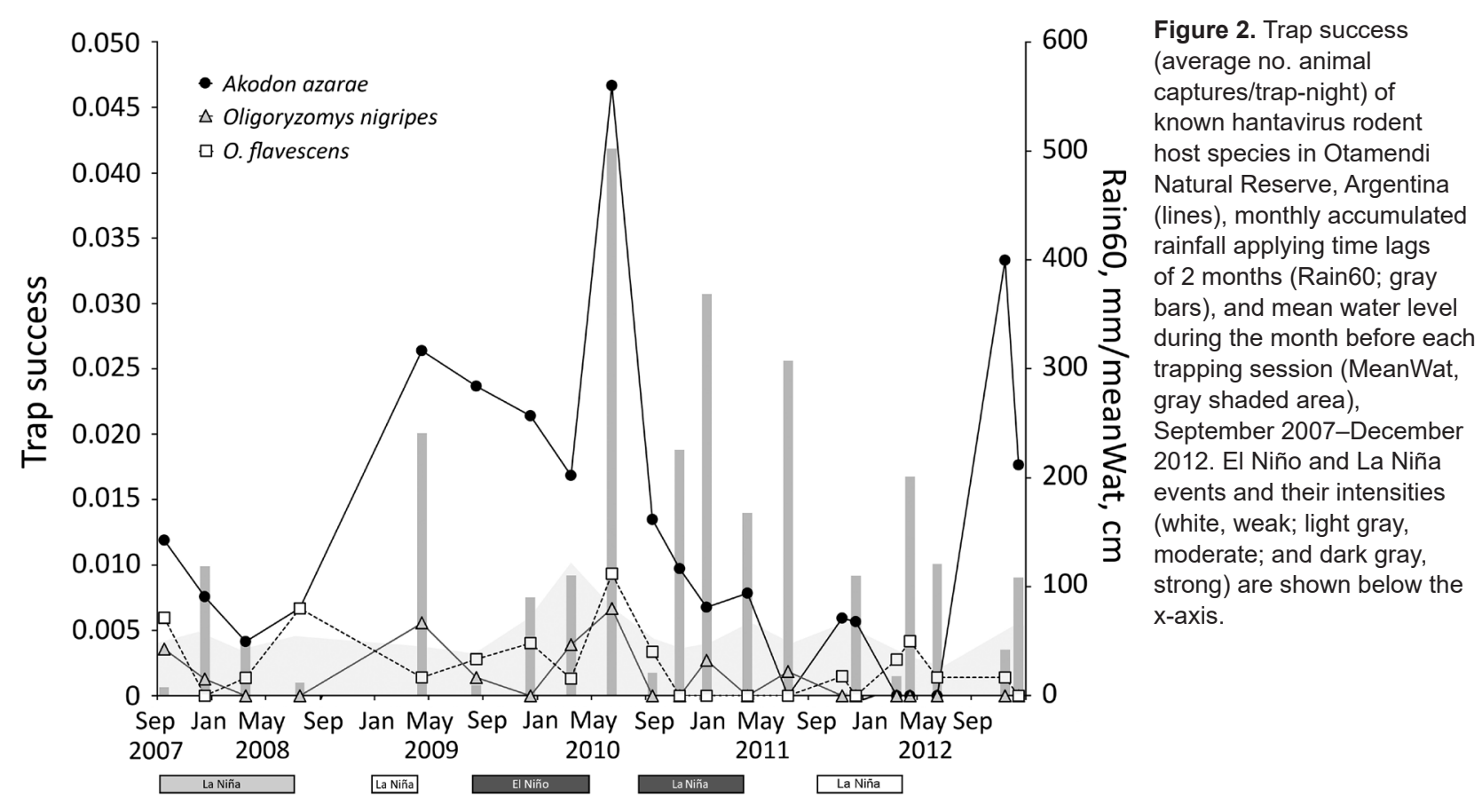

pigmy rice rats are found in many areas, (2), but on the This species was also found in areas with low green basis of our study, prefer habitats with trees (Table 2). broadleaf cover (Table 2).

\begin{tabular}{|c|c|c|c|c|c|c|c|c|c|}
\hline \multirow[b]{2}{*}{ Explanatory variable } & \multicolumn{3}{|c|}{ Akodon azarae grass mouse } & \multicolumn{3}{|c|}{$\begin{array}{l}\text { Oligoryzomys nigripes black- } \\
\text { footed pigmy rice rat }\end{array}$} & \multicolumn{3}{|c|}{$\begin{array}{l}\text { O. flavescens yellow pigmy } \\
\text { rice rat }\end{array}$} \\
\hline & Estimate & SE & $p$ value & Estimate & SE & $p$ value & Estimate & SE & $p$ value \\
\hline Meteorological model & & $28.90 \%)$ & & & $(35.50 \%)$ & & & $15.45 \%)$ & \\
\hline Intercept (riparian forest) & $-2.937^{\mathrm{bc}}$ & 0.604 & $<0.001$ & $6.033^{\mathrm{a}}$ & 0.435 & $<0.001$ & -1.586 & 1.217 & 0.193 \\
\hline Celtis tala forest & $-1.426^{\mathrm{e}}$ & 0.415 & $<0.001$ & $-1.972^{b}$ & 0.678 & 0.004 & - & - & \\
\hline $\begin{array}{l}\text { Lowland grassland with } \\
\text { Cyperaceae spp. }\end{array}$ & $-0.923^{\mathrm{de}}$ & 0.302 & 0.002 & - & - & - & -0.962 & 0.489 & 0.049 \\
\hline $\begin{array}{l}\text { Highland grassland with } \\
\text { Ligustrum spp. }\end{array}$ & $-0.161^{\text {cd }}$ & 0.261 & 0.536 & $-1.555^{b}$ & 0.520 & 0.003 & -1.631 & 0.604 & 0.007 \\
\hline Highland grassland with livestock & $0.169^{\mathrm{ab}}$ & 0.278 & 0.543 & - & - & - & -0.709 & 0.560 & 0.206 \\
\hline Salty grassland & $0.390^{\mathrm{a}}$ & 0.242 & 0.107 & - & - & - & -0.932 & 0.489 & 0.057 \\
\hline Rain60 & 0.002 & 0.001 & 0.001 & 0.006 & 0.002 & $<0.001$ & - & - & - \\
\hline MaxT & -0.049 & 0.018 & 0.005 & - & - & - & -0.120 & 0.040 & 0.002 \\
\hline ONI & 0.513 & 0.098 & $<0.001$ & 0.408 & 0.384 & 0.289 & 0.305 & 0.270 & 0.258 \\
\hline Vegetation model & & $12.34 \%)$ & & & $(11.46 \%)$ & & & $(6.37 \%)$ & \\
\hline Intercept & -3.210 & 0.166 & $<0.001$ & -8.999 & 1.230 & $<0.001$ & -7.070 & 0.459 & $<0.001$ \\
\hline Height & -0.255 & 0.038 & $<0.001$ & - & - & - & - & - & - \\
\hline GBroad & - & - & - & -0.025 & 0.010 & 0.013 & 0.020 & 0.008 & 0.011 \\
\hline Hydrological model & & $22.10 \%)$ & & & $(16.85 \%)$ & & & - & \\
\hline Intercept (riparian forest) & -5.289 & 0.282 & $<0.001$ & -6.068 & 0.636 & $<0.001$ & - & - & - \\
\hline Celtis tala forest & -1.275 & 0.412 & 0.002 & -1.514 & 0.653 & 0.020 & - & - & - \\
\hline $\begin{array}{l}\text { Lowland grassland with } \\
\text { Cyperaceae spp. }\end{array}$ & -0.732 & 0.300 & 0.015 & - & - & - & - & - & - \\
\hline $\begin{array}{l}\text { Highland grassland with } \\
\text { Ligustrum spp. }\end{array}$ & 0.012 & 0.260 & 0.964 & -1.245 & 0.511 & 0.015 & - & - & - \\
\hline Highland grassland with livestock & 0.278 & 0.276 & 0.313 & - & - & - & - & - & - \\
\hline Salty grassland & 0.560 & 0.241 & 0.020 & - & - & - & - & - & - \\
\hline MeanWat & 1.149 & 0.199 & $<0.001$ & 1.183 & 0.585 & 0.043 & - & - & - \\
\hline
\end{tabular}




\section{Conclusions}

Abundance of hantavirus reservoir rodents was influenced principally by meteorologic factors that could be used to predict host population dynamics. However, the presence of hantavirus antibody was mainly influenced by rodent sex and age. Although the prevalence of infection did not vary with environmental factors, greater abundance of hosts indicates a greater absolute number of infected rodents, and therefore, an increased risk for transmission to humans.

\section{Acknowledgments}

We thank Administración de Parques Nacionales for providing logistic support and research permits to work in the Otamendi Natural Reserve; and Á. San Martín, Y. Expósito, F. Castillo, F. García Erice, S. Villareal, S. Calla, L. Aducci, R. Lovera, D. Montes de Oca, M. Feldman, S. Guidobono, and G. Klier for providing invaluable assistance with field work.

This study was supported by Consejo Nacional de Investigaciones Científicas y Técnicas, the Bunge and Born Foundation, and Universidad de Buenos Aires.

Ms. Maroli is a biologist and a PhD student in the Department of Ecology, Genetics, and Evolution at the University of Buenos Aires, Buenos Aires, Argentina. Her research interests are mammal ecology and zoonotic diseases.

\section{References}

1. Palma RE, Polop JJ, Owen RD, Mills JN. Ecology of rodentassociated hantaviruses in the Southern Cone of South America: Argentina, Chile, Paraguay, and Uruguay. J Wildl Dis. 2012;48:267-81. http://dx.doi.org/10.7589/0090-3558-48.2.267

2. de Oliveira R, Guterres A, Fernandes J, D’Andrea PS, Bonvicino CR, de Lemos ER. Hantavirus reservoirs: current status with an emphasis on data from Brazil. Viruses. 2014;6:1929-73. http://dx.doi.org/10.3390/v6051929

3. Padula PJ, Rossi CM, Della Valle MO, Martínez PV, Colavecchia SB, Edelstein A, et al. Development and evaluation of a solid-phase enzyme immunoassay based on Andes hantavirus recombinant nucleoprotein. J Med Microbiol. 2000;49:149-55. http://dx.doi.org/10.1099/0022-1317-49-2-149

4. Vadell MV, Gómez Villafañe IE. Environmental variables associated with hantavirus reservoirs and other small rodent species in two national parks in the Paraná Delta, Argentina. Implications for disease prevention. EcoHealth. 2016;13:248-60. http://dx.doi.org/10.1007/s10393-016-1127-7
5. Grimm AM, Barros V, Doyla ME. Climate variability in southern South America associated with El Niño and La Niña events. Journal of Climate. 2000;13:35-58. http://dx.doi.org/ 10.1175/1520-0442(2000)013<0035:CVISSA $>2.0 . C O ; 2$

6. Zuur AF, Ieno EN, Smith GM. Analyzing ecological data. New York: Springer; 2007.

7. R-Core-Team. R: A language and environment for statistical computing. Version 3.1. Vienna: R Foundation for Statistical Computing; 2013.

8. Vadell MV, Bellomo C, San Martín A, Padula P, Gómez Villafañe E. Hantavirus ecology in rodent populations in three protected areas of Argentina. Trop Med Int Health. 2011;16:1342-52. http://dx.doi.org/10.1111/j.1365-3156.2011.02838.x

9. Maroli M, Vadell MV, Iglesias A, Padula PJ, Gómez Villafañe IE. Daily movements and microhabitat selection of hantavirus reservoirs and other Sigmodontinae rodent species that inhabit a protected natural area of Argentina. EcoHealth. 2015;12:421-31. http://dx.doi.org/10.1007/s10393-015-1038-z

10. Mills JN, Schmidt K, Ellis BA, Calderón G, Enría DA, Ksiazek TG. A longitudinal study of hantavirus infection in three sympatric reservoir species in agroecosystems on the Argentine Pampa. Vector Borne Zoonotic Dis. 2007;7:229-40. http://dx.doi.org/ 10.1089/vbz.2006.0614

11. Polop FJ, Provensal MC, Pini N, Levis SC, Priotto JW, Enría D, et al. Temporal and spatial host abundance and prevalence of Andes hantavirus in southern Argentina. EcoHealth. 2010;7:176-84. http://dx.doi.org/10.1007/s10393-010-0333-y

12. Kuenzi AJ, Morrison ML, Madhav NK, Mills JN. Brush mouse (Peromyscus boylii) population dynamics and hantavirus infection during a warm, drought period in southern Arizona. J Wildl Dis. 2007;43:675-83. http://dx.doi.org/10.7589/ 0090-3558-43.4.675

13. Keesing F, Belden LK, Daszak P, Dobson A, Harvell CD, Holt RD, et al. Impacts of biodiversity on the emergence and transmission of infectious diseases. Nature. 2010;468:647-52. http://dx.doi.org/ 10.1038/nature09575

14. Parmenter RR, Brunt JW, Moore DI, Ernest S. The hantavirus epidemic in the southwest: rodent population dynamics and the implications for transmission of hantavirus-associated adult respiratory distress syndrome (HARDS) in the Four Corners Region. Publication no. 41. Albuquerque (NM): University of New Mexico, Sevilleta Long-Term Ecological Research Site; 1993.

15. Bilenca DN, Kravetz FO. Patterns of relative abundance in assemblages of small rodents in the Pampas region. Austral Ecology. 1995;5:21-30.

Address for correspondence: Isabel E. Gómez Villafañe, Laboratorio de Ecología de Poblaciones, Departamento de Ecología, Genética, y Evolución, Facultad de Ciencias Exactas y Naturales, Universidad de Buenos Aires, Intendente Güiraldes 2160, Ciudad Universitaria C1428EGA, Argentina; email: isabelgv@ege.fcen.uba.ar 